\title{
Diagnostic Value of C-reactive Protein in Complicated Appendicitis
}

\author{
Hyoung-Min Moon, Beom-Seok Park, Duk-Jin Moon \\ Department of Surgery, Kwangju Christian Hospital, Gwangju, Korea
}

Purpose: Early detection of appendicitis has increased due to development of computed tomography and ultrasonography, yet we are frequently meeting complicated appendicitis, including perforation, abscess and a gangrenous appendicitis due to delayed diagnosis. For that reason, we want to evaluate predictive factors for the complicated appendicitis.

Methods: A total of 128 patients with appendicitis, after 13 patients with a duration of under 12 hours and 15 patients with pathological non-appendicitis were excluded from 156 patients, who visited Kwangju Christian Hospital from November 2008 to November 2010 were retrospectively reviewed.

Results: There were 62 patients (48.3\%) with simple appendicitis and 66 patients (51.7\%) with complicated appendicitis. In univariate analysis, age $(\mathrm{P}<0.001)$, C-reactive protein $(\mathrm{P}<0.001)$ and the diameter of the appendix $(\mathrm{P}=0.006)$, were found to be significant. Multivariate analysis demonstrated that $\mathrm{C}$-reactive protein was an independent predictor for complicated appendicitis (odds ratio, 1.371; 95\% confidence interval, 1.155 to $1.628 ; \mathrm{P}<0.001$ ). The cut-off value of $\mathrm{C}$-reactive protein was set at $7.05 \mathrm{mg} / \mathrm{dL}$ by using receiver operating characteristic curve ( 0.805 ; sensitivity, $57.6 \%$; specificity, $98.3 \%)$.

Conclusion: This study suggests that if C-reactive protein is above $7.05 \mathrm{mg} / \mathrm{dL}$, immediate and proper management should be performed due to a high probability of complicated appendicitis, especially in young children or elderly patients who frequently present with vague symptoms.

\section{Keywords: Complicated appendicitis; C-reactive protein; Predictive factor}

\section{INTRODUCTION}

Acute appendicitis is a common disease with an incidence of $42-$ 175 in 100,000 persons. Nonetheless, because of its atypical symptoms and difficulties in making a definite diagnosis, only $84 \%$ of the patients who undergo an appendectomy manifest pathological findings of appendicitis $[1,2]$. If it is diagnosed as simple appendicitis, the recovery time is relatively short time without any complications. However, in perforated or gangrenous appendicitis due to the delay of operation, the hospital stay, the cost, and the incidence of early, as well as delayed, complications are increased dras-

Received: March 3, 2011 Accepted: May 21, 2011

Correspondence to: Hyoung-Min Moon, M.D.

Department of Surgery, Kwangju Christian Hospital, 264 Yangnim-dong,

Nam-gu, Gwangju 503-715, Korea

Tel: +82-62-650-5036, Fax: +82-62-671-7447

E-mail: legus75@hanmail.net

(C) 2011 The Korean Society of Coloproctology

This is an open-access article distributed under the terms of the Creative Commons Attribution NonCommercial License (http://creativecommons.org/licenses/by-nc/3.0) which permits unrestricted noncommercial use, distribution, and reproduction in any medium, provided the original work is properly cited. tically. Therefore, it is no question that early detection and proper treatment for appendicitis is able to minimize postoperative complication [3].

Recently, the incidence of early diagnosis and treatment for acute appendicitis is high due to improvement of radiologic evaluation using computed tomography and ultrasonography, but the incidence of early detection for complicated appendicitis is still limited. Currently, the diagnosis of complicated appendicitis depends on the onset of symptoms and physical examination; thus, inaccuracy due to subjective interpretation is common. For that reason, we wanted to seek objective and accurate test methods with predictive factors for complicated appendicitis with perforation, abscess formation or gangrenous change.

\section{METHODS}

From November 2008 to November 2010, 156 patients underwent emergency appendectomy at Kwangju Christian Hospital. Among them, fifteen patients who have no pathologic appendicitis and 13 whose onset of symptoms was within 12 hours were excluded. Ultimately, a total of 128 patients were enrolled in this study. Based 
on the medical records of patients, gender, age, duration of symptoms, the Alvarado score, C-reactive protein, pathologic findings, results of computed tomography or ultrasonography, and methods of operation were examined retrospectively. The Alvarado score is based on clinical features, as well as laboratory findings. Migration pain is 1 point, anorexia is 1 point, nausea or vomiting is 1 point, tenderness in the right lower abdomen is 2 points, rebound tenderness is 1 point, fever is 1 point, leukocytosis is 2 points, and neutrophilic shift to the left is 1 point. The total score is 10 points, and the normal range of leukocystosis is different, depending on age (Table 1) [4].

In regard to surgical methods, depending on the ability and the decision of the surgeon, a laparoscopic or open appendectomy was performed. For cases with risks for hemorrhage or leakage and in appendicitis with perforation, formation of abscess, or gangrenous change, drainage tubes were inserted. Based on surgical or pathologic findings, cases with gangrenous change, perforation, or abscess formation were classified as C-type (complicated) appendicitis, and the others were classified as S-type (simple) appendicitis.

In our study, for statistical analysis, the SPSS ver. 12.0 (SPSS Inc.,

Table 1. Alvarado scoring system

\begin{tabular}{|c|c|}
\hline Features & Score \\
\hline \multicolumn{2}{|l|}{ Symptoms } \\
\hline Migration of pain & 1 \\
\hline Anorexia & 1 \\
\hline Nausea/vomiting & 1 \\
\hline \multicolumn{2}{|l|}{ Signs } \\
\hline Tenderness in the right lower abdomen & 2 \\
\hline Rebound tenderness & 1 \\
\hline Elevated temperature $\left(\geq 37.3^{\circ} \mathrm{C}\right)$ & 1 \\
\hline \multicolumn{2}{|l|}{ Laboratory test } \\
\hline Leukocytosis $^{\mathrm{a}}$ & 2 \\
\hline Neutrophilic shift to the left ${ }^{\mathrm{b}}$ & 1 \\
\hline Total score & 10 \\
\hline
\end{tabular}

Chicago, IL, USA) logistic regression analysis was applied. The cutoff value of C-reactive protein was defined by drawing the receiver operating characteristic (ROC) curve with the relationship of sensitivity and specificity and obtaining the highest Youden index.

\section{RESULTS}

\section{Results of pathology and operation}

Based on pathologic or surgical findings, simple appendicitis was present in 62 patients (48.4\%), perforated appendicitis in 22 patients (17.2\%), gangrenous appendicitis in 20 patients (15.6\%), and gangrenous appendicitis together with perforation in 24 patients (18.8\%).

\section{Gender and age}

Seventy patients $(54.6 \%)$ were male, and 58 patients (45.4\%) were female; the average age was $37.88 \pm 23.80$ years. The age distribution was as follows; 27 patients (20.3\%) were 0 to 12 years, 12 patients $(9.3 \%)$ were 13 to 19 years, and 89 patients $(70.3 \%)$ were older than 20 years. The incidence of C-type appendicitis became higher as age increased $(\mathrm{P}<0.001)$ (Table 2$)$.

\section{The Alvarado score}

The Alvarado score was distributed from 2 points to 10 points, the total mean was $6.16 \pm 1.75$ points, and at 7 points, the incidences of both C-type and S-type appendicitis were high. The mean for S-type appendicitis was $6.03 \pm 1.89$ points, and that for C-type appendicitis was $6.28 \pm 1.61$ points. The Alvarado score did not significantly correlate to $\mathrm{C}$-type appendicitis $(\mathrm{P}=0.421)$.

\section{Laboratory findings}

In blood test, in regard to the leukocyte count, the mean for all cases was $1,3142 \pm 4,154 / \mathrm{mm}^{3}$, that for S-type appendicitis was $12,946 \pm 4,316 / \mathrm{mm}^{3}$, and that for C-type appendicitis was 13,337 $\pm 4,010 / \mathrm{mm}^{3}$, but these differences were not statistically significant $(\mathrm{P}=0.594)$. Regarding $\mathrm{C}$-reactive protein, the mean for all patients was $5.96 \pm 8.36 \mathrm{mg} / \mathrm{dL}$, that for S-type appendicitis was $1.82 \pm 2.29$ $\mathrm{mg} / \mathrm{dL}$, and that for C-type appendicitis was $10.10 \pm 10.05 \mathrm{mg} / \mathrm{dL}$. The univariate analysis showed C-reactive protein to be a signifi-

Table 2. General characteristics and univariate analysis according to types of appendicitis

\begin{tabular}{|c|c|c|c|c|}
\hline Variables & Simple type $(n=62)$ & Complicated type $(n=66)$ & Total $(n=128)$ & P-value \\
\hline Age (yr) & $28.56 \pm 20.95$ & $47.19 \pm 22.94$ & $37.88 \pm 23.80$ & $<0.001$ \\
\hline Alvarado score & $6.03 \pm 1.89$ & $6.28 \pm 1.61$ & $6.16 \pm 1.75$ & 0.421 \\
\hline $\mathrm{CRP}$ (mg/dL) & $1.82 \pm 2.29$ & $10.10 \pm 10.05$ & $5.96 \pm 8.36$ & $<0.001$ \\
\hline Duration (hr) & $31.53 \pm 38.09$ & $43.56 \pm 32.28$ & $37.55 \pm 35.68$ & 0.065 \\
\hline
\end{tabular}

Values are presented as mean $\pm \mathrm{SD}$.

WBC, white blood cell; CRP, C-reactive protein. 
cant factor for C-type appendicitis $(\mathrm{P}<0.001)$. In multivariate analysis, similarly, C-reactive protein independently showed a significant correlation to $\mathrm{C}$-type appendicitis $(\mathrm{P}<0.001$; odds ratio, 1.371; 95\% confidence interval, 1.155 to 1.628 ) (Table 3 ).

The area under the curve (AUC) of ROC curve was shown to be 0.805 (Fig. 1), and the highest Youden index was obtained by applying sensitivity and specificity. When C-reactive protein was 7.05 $\mathrm{mg} / \mathrm{dL}$, the Youden index was 0.543 , the highest, and at this value, the sensitivity was $57.6 \%$, the specificity was $98.3 \%$, the positive predictive value was $97.4 \%$, and the negative predictive value was 68.5\% (Table 4).

\section{Imaging studies}

Ultrasonography was performed on 41 patients, computed tomography was performed on 64 patients, and both tests were performed on 5 patients. At our hospital, standard criteria for diagnosis using imaging studies of appendicitis is that the diameter of the appendix be larger than $6.7 \mathrm{~mm}$. The mean for all cases was $10.27 \pm 3.54$ $\mathrm{mm}$, that for S-type appendicitis was $9.36 \pm 3.29 \mathrm{~mm}$, and that for C-type appendicitis was $11.36 \pm 3.55 \mathrm{~mm}$. As the diameter of the appendix became larger, the incidence of C-type appendicitis became higher $(\mathrm{P}=0.006)$.

Of the total 41 patients on whom ultrasonography had been performed, the pathologic findings indicted S-type appendicitis to be present in 33 patients and C-type appendicitis in 8 patients, but all were diagnosed as having simple appendicitis with no mention of complicated appendicitis. Of the 64 patients on whom computed tomography had been performed, the pathologic findings indicated S-type appendicitis to be present in 31 patients and C-type appendicitis in 33 patients; only 8 patients were diagnosed as having perforated appendicitis or appendicitis with an abscess (Table 5).

Table 3. Results of multivariate analysis

\begin{tabular}{lccc}
\hline & Odds ratio & $\begin{array}{c}95 \% \text { confidence } \\
\text { interval }\end{array}$ & P-value \\
\hline Age & 1.034 & $1.007-1.062$ & 0.013 \\
Sex & 0.406 & $0.132-1.251$ & 0.117 \\
Alvarado score & 1.281 & $0.918-1.788$ & 0.144 \\
C-reactive protein & 1.371 & $1.155-1.628$ & $<0.001$ \\
Size of appendix & 1.222 & $1.048-1.425$ & 0.010 \\
Duration of symptom & 0.983 & $0.966-1.000$ & 0.048 \\
\hline
\end{tabular}

\section{Duration of symptoms}

The duration from the onset of symptoms to the time of admission was recorded by inquiry. For all patients, the mean during from onset of symptoms to admission was $37.55 \pm 35.68$ hours, for patients with S-type appendicitis, it was $31.53 \pm 38.09$ hours, and for patients with C-type appendicitis, it was $43.56 \pm 32.28$ hours. The durations of the symptoms and the types of appendicitis showed no significant differences $(\mathrm{P}=0.065)$.

\section{DISCUSSION}

The incidence of perforated or gangrenous appendicitis is high in the young children or the elderly, which reflects that their presenting symptoms are not typical, so it is difficult to diagnose the dis-

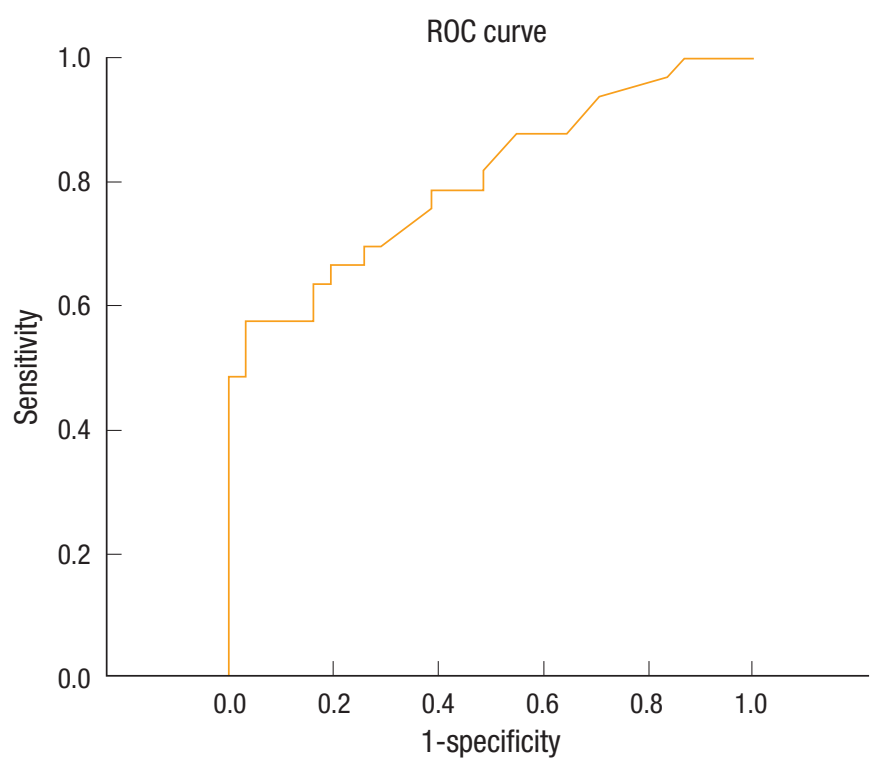

Fig. 1. Receiver operating characteristic (ROC) curve of C-reactive protein.

Table 5. Findings of ultrasonography or CT

\begin{tabular}{lccc}
\hline & $\begin{array}{c}\text { No. of S type } \\
\text { appendicitis }\end{array}$ & $\begin{array}{c}\text { No. of C type } \\
\text { appendicitis }\end{array}$ & Total \\
\hline Ultrasonography & $33(41)$ & $8(0)$ & $41(41)$ \\
CT & $31(56)$ & $33(8)$ & $64(64)$ \\
\hline
\end{tabular}

No. in parenthesis means the number of patients positively diagnosed by ultrasonography or computed tomography (CT).

Table 4. Specificity and sensitivity of C-type appendicitis in CRP $7.05 \mathrm{mg} / \mathrm{dL}$

\begin{tabular}{|c|c|c|c|c|c|c|}
\hline $\mathrm{CRP}(\mathrm{mg} / \mathrm{dL})$ & No. of C type & No. of S type & Sensitivity (\%) & Specificity (\%) & PPV (\%) & NPV (\%) \\
\hline$\geq 7.05$ & 38 & 1 & & & & \\
\hline$<7.05$ & 28 & 61 & & & & \\
\hline Total & 66 & 62 & 57.6 & 98.3 & 97.4 & 68.5 \\
\hline
\end{tabular}

CRP, C-reactive protein; PPV, positive predictive value; NPV, negative predictive value. 
ease early. Kim et al. [3] reported that the incidence of perforated or gangrenous appendicitis was significantly high in patients who were older than 40 years. In our study, similarly, as patients became older, the incidence of complicated appendicitis also became significantly higher.

Alvarado [5] scored the clinical symptoms of appendicitis patients and used laboratory results to classify them into three groups: patients with 7-10 points, who were strongly suspected of having acute appendicitis and needed to undergo immediate surgery, patients with 0-4 points, who because of the low possibility of having acute appendicitis were discharged without additional evaluation, and patients with 5-6 points, who were difficult to diagnose only by the scores and for whom further evaluation was recommended for a definitive diagnosis of acute appendicitis. In our study, 28 patients (21.9\%) had an Alvarado score lower than 4 points, and among them, S-type appendicitis was present in 13 patients (10.2\%) and C-type appendicitis in 15 patients (11.7\%). Thus, we conclude that for patients with lower points, their symptoms are nonspecific, resulting in delayed diagnosis and increased possibility of developing complicated appendicitis.

C-reactive protein is an acute inflammatory protein and was separated from the serum of pneumococcal pneumonia patients for the first time because it binds to pneumococcal $\mathrm{C}$ polysaccharide and forms precipitates. Because such reactions were found to occur in other acute infections, C-reactive protein has been used as a marker of acute infections [6]. Physiologically, it has been shown to accelerate phagocytic reactions and chemotaxis, to activate platelets, and thus to increase cell-mediated immunity [7]. It is an early marker of appendicitis and myocardial infarction, and it has been reported to be increased in patients with pneumonia, pancreatitis, pelvic inflammation, and urinary tract infection or in patients in whom treatment of these diseases had failed. It can be used to evaluate the severity of intravascular diseases or asymptomatic patients with risk factors for cardiovascular diseases who require treatment, and for monitoring of rheumatoid arthritis and inflammatory bowel disease, with which the value of C-reactive protein correlates [8].

In 1984, for the first time, studies on the relation of acute appendicitis with serum C-reactive protein were reported. In the study reported by Mikaelsson and Arnbjornsson [9] that was conducted on 156 pediatric patients, patients with normal C-reactive protein prior to surgery showed a normal appendix or a phlegmonous appendix in operative findings. Patients with elevated C-reactive protein had mesenteric lymphadenitis or acute appendicitis, and when the inflammatory severity of appendicitis was more or the disease duration was longer, higher C-reactive protein values were shown.

In several studies, the sensitivity of C-reactive protein for the diagnosis of acute appendicitis was $40-87 \%$, the specificity was $53-$ $82 \%$, and diverse results were reported [10]. In our study, significantly elevated C-reactive protein was shown in complicated appendicitis, and in all patients with C-reactive protein above $9.9 \mathrm{mg} /$ dL, complicated appendicitis was shown. Park et al. [11] stated that in patients with very high C-reactive protein, the inflammation degree of appendicitis was very severe, or diseases other than appendicitis were present. The average serum C-reactive protein of patients with gangrenous or perforated appendicitis has been reported to be $9.76 \mathrm{mg} / \mathrm{dL}$, and no correlation of leukocytes with serum C-reactive protein values has been reported.

Bickell et al. [12] reported in a study conducted on a patient group with ages from 5 years to 80 years that in patients whose duration from the onset of symptoms to operation time was longer than 36 hours, the risk for the development of perforated appendicitis was high. However, in our study, the duration to operation did not significantly correlate to complicated appendicitis. We think that patients may have reported the wrong onset of symptoms or that communications with young children may have been difficult or unclear; thus, wrong times may have been recorded in the medical records.

Abdominal sonography is a sensitive tool that can be performed very easily; it is not harmful to patients, and its cost is low. Thus, together with computed tomography, it has been used as a supplement diagnostic tool, leading to an increased rate of definite diagnosis. Consequently, early diagnosis and appropriate treatments has become feasible. The sensitivity of ultrasonography is $85-99 \%$, and its specificity is $90-99 \%$. Nonetheless, ultrasonography cannot penetrate air or bone, so its results vary greatly depending on the radiologist. On the other hand, diverse sensitivities, specificities and accuracies have been reported for computed tomography [13]. Wijetunga et al. [14] reported a 93\% sensitivity and a 97\% specificity. Cho et al. [13] reported the sensitivity and the specificity of computed tomography for the detection of inflammation in adipose tissues in the vicinity of the appendix to be $77 \%$ and $83 \%$, respectively, and the sensitivity and the sensitivity to detect abscesses to be $18 \%$ and $75 \%$.

The treatment for perforated appendicitis is still controversial because of diverse views. Nonetheless, for perforated appendicitis, Noh et al. [15] stated that in pediatric patients, immediately after the diagnosis of perforated appendicitis, conservative treatments, such as administrating antibiotics and replacing fluid, electrolytes, etc., are desirable; emergency surgery at night should be avoided, and an elective appendectomy should be performed during the day. On the other hand, Lee et al. [16] stated that the delay to an appendectomy in adult patients is a risk factor for the progression to complicated appendicitis, so the operation should be performed as soon as possible.

Based on these results, we conclude that complicated appendicitis may exert great influence on its treatment methods and prognosis, so we examined various diagnosis methods. The conventional diagnosis method is based on the onset of symptoms and on physical examination; thus, complicated appendicitis may be diagnosed inaccurately because of the subjective judgment of an inexperienced physician who initially diagnosed it at the emergency room. In our study, complicated appendicitis could be predicted by using C-reactive protein, which is objective, relatively inexpensive, and simple. However, it is desirable to conduct data 
analysis on more patient groups. Finally, if prospective studies on the association of $\mathrm{C}$-reactive protein with the results of detailed physical examination, which could not be addressed in our study, are conducted, a more accurate basis for the diagnosis of complicated appendicitis might be found.

In conclusion, the incidence of complicated appendicitis became higher as patients became older, the diameter of the appendix on radiological imaging became larger, and the value of C-reactive protein became higher. However, for diagnosis, it was difficult to define any appropriate cut-off value of age and radiological imaging methods. In complicated appendicitis, C-reactive protein was shown to average $10.10 \mathrm{mg} / \mathrm{dL}$. In cases whose cut-off value obtained from the ROC curve was $7.05 \mathrm{mg} / \mathrm{dL}$, the sensitivity for the diagnosis of complicated appendicitis was $57.6 \%$, the specificity was $98.3 \%$, the positive predictive value was $97.4 \%$, and the negative predictive value was $68.5 \%$. In conclusion, in patients who have already been diagnosed as having appendicitis and for whom surgery has already been scheduled, if the value of C-reactive protein is higher than $7.05 \mathrm{mg} / \mathrm{dL}$, to the surgeon should anticipate complicated appendicitis, decide on an appropriate operation time, select antibiotics, and explain the prognosis to the patient.

\section{CONFLICT OF INTEREST}

No potential conflict of interest relevant to this article was reported.

\section{REFERENCES}

1. Kozar RA, Roslyn JJ. The Appendix. In: Schwartz SI, Shires GT, Spencer FC, Daly JM, Fischer JE, Galloway AC, editors. Principles of surgery. 7th ed. New York, NY: McGraw-Hill; 1999. p. 1383-94.

2. Pieper R, Kager L, Nasman P. Acute appendicitis: a clinical study of 1018 cases of emergency appendectomy. Acta Chir Scand 1982; 148:51-62.

3. Kim JI, Seong MK, Lee KY. Preoperative prediction of acute perforative and gangrenous appendicitis by clinical features of pa- tients. J Korean Surg Soc 1993;44:1048-60.

4. Oh BY, Kim KH, Lee RA, Chung SS. Diagnostic efficacy of the Alvarado score according to age in acute appendicitis. J Korean Surg Soc 2010;78:100-5.

5. Alvarado A. A practical score for the early diagnosis of acute appendicitis. Ann Emerg Med 1986;15:557-64.

6. Tillett WS, Francis T. Serological reactions in pneumonia with a non-protein somatic fraction of pneumococcus. J Exp Med 1930; 52:561-71.

7. Zimmerman MA, Selzman CH, Cothren C, Sorensen AC, Raeburn CD, Harken AH. Diagnostic implications of C-reactive protein. Arch Surg 2003;138:220-4.

8. Clyne B, Olshaker JS. The C-reactive protein. J Emerg Med 1999; 17:1019-25.

9. Mikaelsson C, Arnbjornsson E. The value of C-reactive protein (CRP) determinations in patients with suspected acute appendicitis. Ann Chir Gynaecol 1984;73:281-4.

10. Young B, Gleeson M, Cripps AW. C-reactive protein: a critical review. Pathology 1991;23:118-24.

11. Park CJ, Chung WS, Chang TS. The diagnostic value of serum Creactive protein in patients suspected to have acute appendicitis. J Korean Surg Soc 1997;53:252-7.

12. Bickell NA, Aufses AH Jr, Rojas M, Bodian C. How time affects the risk of rupture in appendicitis. J Am Coll Surg 2006;202:401-6.

13. Cho HJ, Whang IY, Kim JI, Ahn CH, Kim JS, Yoo SJ, et al. The role of abdomen-pelvis CT for the diagnosis of appendicitis. J Korean Surg Soc 2008;75:90-5.

14. Wijetunga R, Tan BS, Rouse JC, Bigg-Wither GW, Doust BD. Diagnostic accuracy of focused appendiceal CT in clinically equivocal cases of acute appendicitis. Radiology 2001;221:747-53.

15. Noh KT, Chung SS, Choi KJ. Optimal time for appendectomy in perforated appendicitis of children. J Korean Surg Soc 2010;78: 242-8.

16. Lee MA, Chung M, Lee YD, Lee JN, Lee WK, Park YH, et al. The effect of delayed surgery in adult patients with acute appendicitis. J Korean Surg Soc 2009;76:360-3. 